\title{
Crime Murder Investigation Process of Infant in Order by Biological Mother on Child Protection in Polres Purworejo Jurisdiction (Case Study in Polsek Butuh Purworejo)
}

\author{
Yuliantoro $^{1}$ and Akhmad Khisni ${ }^{2}$
}

Abstract. The aim in this study were 1) to determine analyze the process of investigation of criminal infanticide by the biological mother in Polsek Butuh Purworejo; 2) to assess and analyze the process of investigation of criminal infanticide by the biological mother can provide protection for children; and 3 ) to study and analyze the obstacles encountered in the process of criminal investigation of infanticide by the biological mother. The method used in this research is empirical juridical approach or in other words the socio-juridical. Specifications of this research is descriptive. Data used in this study are primary and secondary data. The collection of data used in this research is to study literature and interviews. Analysis of the data used in this study is qualitative. In this study thatcriminal investigation process by the biological mother infanticide in Purworejo district police Butuh a police station covering the investigator, attack, inspection, and final completion and submission of the case file. The process of criminal investigation of infanticide by the biological mother can provide protection for children, in addition to whether or not made his case investigation conducted by the police of all elements also determine the chapter to be used against the offender. Investigators in the case of infanticide ensnared by the biological mother can use Article 80 paragraph (3), (4) by Act No. 35 Of 2014 on Amendment Act No. 23 of 2002 on the Protection of the Child, Article 338 of the Criminal Code. In the process of investigation of criminal offenses committed infanticide by the biological mother still there are issues both internally and externally, namely the ability of investigators that witnesses are hard to find at the scene.

Keywords: Investigation; Crime; Killing Infant; Child Protection.

\section{Introduction}

In the legislation in Indonesia teah clear set of objectives the protection of children in article 3 of Act No. 23 of 2002 on the protection of children, namely that:

"Child protection aims to ensure the fulfillment of children's rights in order to live, grow, develop and participate optimally in accordance with the nature and dignity of humanity, and to protection from violence and discrimination in order to achieve quality of Indonesian children, berakhlaq glorious and prosperous".

It is the right of every child to be free from violence and free from all forms of violent content, regardless of time and place. Thus it is the responsibility of all parties to protect children from acts that make children's rights are not fulfilled. ${ }^{3}$ Every child has

\footnotetext{
${ }^{1}$ Student of Master of Law, Universitas Islam Sultan Agung Semarang and Police Members Officer email: syarifudinarif130398@gmail.com

${ }^{2}$ Lecturer of Faculty of Law Unissula Semarang

3 Evi Deliana HZ "Perlindungan Hukum terhadap anak dari konten berbahahaya dalam media cetak elektronik," Jurnal IImu Hukum, Faculty of Law, University of Riau, August 2002 Edition III.
} 
the right to obtain legal protection from all forms of physical or mental violence, neglect, mistreatment and sexual abuse for the parent or guardian's care or any other party which bertanggungjawa limit the child care. ${ }^{4}$

But lately often parents who treat their children with improper conduct carried out, which should parents give attention instead to let their children affection displaced. Child neglect is a form of violence against children in the family.

In this case not all community members willing to obey, and still there is deviant behavior, which generally are less favored by the public. The increasing criminality in Indonesia resulted in the emergence of various modus operandi in criminal acts. Besides, the lack of public knowledge about criminal law led to a fall victim to a crime or a criminal offender. One crime that occurred in the community is the crime of infanticide.

Crimes committed by the mother against her own son declared as something impossible happen if there are specific reasons (secreet factors). Dumping and infanticide are more prone to psychiatric problems, pressure or psychological burden borne by a mother to child birth. ${ }^{5}$

Baby murder case occurred in the village of the District Binangun Butuh Purworejo on October 6, 2017. A local irrigation officials find an open plastic bag visible hand of a baby's foot and irrigation canals, and witnesses reported to the Police Butuh, after getting reports picket reskrim rushed to the scene and true that there is a plastic bag that contained a baby, and a witness along with picket Criminal immediately brought to the hospital Tjitro wardoyo Purworejo for autopsy and it turns out that doing his own mother. Purworejo district police themselves have reported that every of 20172018 there will always be cases of infanticide were done on his own mother, it can be seen in the following table.

Table 1

Police Baby Murder Case Data Purworejo Of 2017-2018

\begin{tabular}{|l|l|l|l|l|}
\hline Year & Amount & CT & CC & Information \\
\hline 2017 & 3 & 3 & 1 & Sidik process 1 and Lidik 2 \\
\hline 2018 & 2 & 2 & - & process Lidik \\
\hline
\end{tabular}

Source: Data Police Purworejo

According to the table above shows that each year Purworejo district police received a case of infanticide, which in the of 2017 the total number of crimes (CT / Crime Total) 3 cases, but only one case reported to the police and the courts resolved (CC / Crime Clearance). Meanwhile, in 2018 the total number of crimes (CT / Crime Total) by 2 cases and no one has completed its investigation. Lack of community participation and still many obstacles in the investigation process led to cases of infanticide unresolved. Indonesian society conditions resulted in shifts in a negative value. Where people are only concerned with their personal interests without consideration for the rights that exist in the community itself, giving rise to crime. One can not distinguish between good and evil that will eventually emerge a society who think only of worldly pleasures

\footnotetext{
${ }^{4}$ Article 58 paragraph 1 of the Act of the Republic of Indonesia Number 39 of 1999 on Human Rights

${ }^{5}$ Herdian Ayu Andreana Beru Tarigan 2018 Upaya Penanggulangan Tindak Pidana Pembuangan Bayi di Kabupaten Boyolali Publication Paper, Faculty of Law, University of Muhammadiyah Surakarta p. 3.
} 
such as free sex, prostitution, murder, gambling, rape, juvenile delinquency. Moral damages resulting someone does not heed the norms of decency in society which resulted in the crime rate to be increased.

Crimes committed by a mother kills baby who is a big enough problem that asks a lot of attention from the public in general and law enforcement officials in particular. In this case the more important role of local communities in solving the murder of a baby in comparison with law enforcement. Wherein in case of crimes committed infanticide own mother, then the community must report it to law enforcement authorities for the maasyarakat expected to participate in the investigation process infanticide committed by his biological mother.

With the presence of matter or criminal acts by unscrupulous mother, the writer would like the theme of the investigation that an examination by the investigator (police) in the case that seeks to conduct an examination of the alleged offender is a murderer of his own mother.

Based on the description above, the writer interested to do research with the title "Crime Murder Investigation Process Of Infant In Order By Biological Mother On Child Protection In Polres Purworejo Jurisdiction (Case Study In Polsek Butuh Purworejo)". Based on the above background, the issues to be discussed are: 1) how the process of investigation of criminal infanticide by the biological mother in Polsek Butuh Purworejo?; 2) whether the process of investigation of criminal infanticide by the biological mother can provide protection for children?; 3) what constraints encountered in the process of criminal investigation by the biological mother infanticide in Polsek Butuh Purworejo? As well, what's the solution?

\section{Research Methods}

The method used in this research is empirical juridical approach or in other words the socio-juridical. Specifications of this research is descriptive, because the specifics of this study aims to describe the problem in this research. ${ }^{6}$ Data used in this study are primary and secondary data. The collection of data used in this research is to study literature (Library Research) and interviews (informant: Bripka Rachmat Widodo, SH, and Inspector Setio Raharjo, SH). Data analysis is the process of organizing the data so that the data can be interpreted. ${ }^{7}$ In this case the analysis of qualitative data is data which can not be measured or judged by the numbers directly. ${ }^{8}$

\section{Results and Discussion}

\subsection{Crime Investigation process infanticide By Mother Bladder What's In Polsek Butuh Purworejo}

That the process of criminal investigation conducted by the police infanticide is a subsystem of the Criminal Justice System, which consists of Police (Investigator), Attorney (Prosecutor), and the court / judge (breaker case). In conducting the investigation process underlying the Police laws and regulations the applicable

\footnotetext{
${ }^{6}$ Ibid. Page 42.

${ }^{7}$ Dadang Kahmad 2000 Metode Penelitian Agama CV Pustaka Setia Bandung p. 102.

${ }^{8}$ Tatang M. Aminrin 2000 Menyusun Rencana Penelitian PT. Raja Grafindo Persada Jakarta p. 134.
} 
provisions by upholding the code of ethics and human rights. Ethics of the legal profession should guide the law enforcement agencies in carrying out their duties and obligations to create order in society. Professional Code of Conduct is not only used as a display that adorn the walls.

In the International Association of Chiefs of Police, 1970, which contains the Law Enforcement Code of Ethics, among others determined As a law Enforcement Officer, my fundamental duty is to serve mankind, to safeguard lives and property; protect the innocent againts deception, the weak against oppression or intimidation, and the peaceful against violence or disorder; and to respect the rights of all man constituonal liberty, equality and justice. ${ }^{9}$ The most important thing in law enforcement must be based on the conscience of conscience we can judge whether our actions are inhumane, unjust, improper, and honest. ${ }^{10}$ The main activities in the framework of criminal investigations process includes:

- Investigators

- Presecutor

- Callings

- Arrest

- Detention

- Search

- Foreclosure

- Examination

- Witness

- Expert

- Suspect

- Completion and submission dossiers

- Resume manufacture

- Preparation of case files

- Submission of dossiers

Of the four main activities of the process of investigation of infanticide, the results must meet the formal requirements regarding the format of the administrative investigation is usually female investigator in the case, with the reason a woman is more subtle and patient in making pemeriksaan.dan material requirements are that the substance of the Law (elements chapter presupposed) Article 341 of the Criminal Code, and Article 342 of the Criminal Code which both must be met. In addition to in order to support verification as described, then the investigator should be assisted by the support of Department of Forensic Medicine in order to achieve the results of the investigation more professional and scientific, and also in order to create a culture of criminalistic mindedness. ${ }^{11}$

\footnotetext{
${ }^{9}$ Richard Quinney 1975 Criminology Analysis and Critique of crime in America Little Brown and Company Boston Toronto p. 35.

10 Nyoman Serikat Putera Jaya 1998 Penegakan Hukum Dalam Era Reformasi Delivered at an open senate meeting university of pekalongan, in the program of dies natalis XVI and under graduate convocation XII 5 September 1998.

${ }^{11}$ Kepolisian Negara Republik Indonesia Daerah Istimewa Yogyakarta Peran Scientificlnvestigation dalam Pengungkapan Kecelakaan/Kejahatan terhadap Manusia Paper stated in Medical Scientific Research
} 


\subsection{Crime Investigation process infanticide By Sibling Such Mom Can Provide Protection For Children}

Purworejo himself at the police station cases of infanticide by the biological mother during the years 2017 until now there are a few cases. In the case of the discovery of a dead baby by the biological mother, the evidence of a dead baby that was taken from the scene by police Forensic Medicine submitted to the nearest hospital with the attached application for a post mortem. Presented bylptu Setio Raharjothat every police found a dead baby always ask to do a post mortem at the Forensic Medicine Hospital nearest the destination will be used as evidence if a day has been found a dead baby or the parents of the perpetrators of the murder of the baby. From the results of a post mortem can be known causes of infant mortality.

In addition to whether or not made his case investigation conducted by the police of all elements also determine the chapter to be used against the offender. Investigators in the case of infanticide ensnared by the biological mother can use Article 80 paragraph (3), (4) by Act No. 35 Of 2014 on Amendment Act No. 23 of 2002 on the Protection of the Child, Article 338 of the Criminal Code, Article 181 of the Criminal Code, Article 341 of the Criminal Code and Article 342 of the Criminal Code or if possible can also put another article that satisfies the element.

In distinguishing between ordinary murder, manslaughter, infanticide and abortion, the police see the motive of the act first if the intent to kill that appear when the baby is still in the womb or when he knows has given birth to a baby that he himself does not know when the baby will born. But the Law Child Protection Act are not concerned about whether the act was carried out with the plan or not, but rather the act was committed with violence or cruelty that resulted in death. When viewed from the body of the infanticide form the baby's body had been intact while abortion is not perfect body shape.

The task of the investigator is to create a file and search and collect evidence where the evidence is making light of a crime is happening and to find the suspects. In the file to the prosecutor's delegate investigators regardless of whether the case was later by the judge will be found guilty or not, the police authorities are processing a case which was brought forward.

In looking at the public prosecutor prejudice to the provisions of Article 63 paragraph (2) of the Criminal Code. Where is the crime of infanticide is also stipulated in the Act More specific legislation that is in Article 80 paragraph (3), (4) by Act No. 35 Of 2014 on Amendment Act No. 23 of 2002 on Child Protection. According to the author of the Public Prosecutor in indicting the defendant should use more specific rules, Article 80 paragraph (3), (4) by Act No. 35 Of 2014 on Amendment Act No. 23 of 2002 on Child Protection in the indictment but this article is no specified. 


\subsection{Obstacles Faced in the Process of Investigation Crime infanticide By Mother Bladder What's In Polsek Butuh Purworejo and Solutions Faced with these constraints}

In the process of investigation of criminal offenses committed infanticide by the biological mother in Kendal there were limited both internally and externally, among others:

- Internally;

- The ability of investigators remains limited to legislation as well as the understanding of the role of forensics.

- Support equipment and operational costs in the field of investigation is limited yan.

- Externally;

- Awareness and understanding of the general public against the law still does not give a positive contribution.

- There's also people's reluctance to be willing to be a witness in the interests of the investigation.

- At crime scenes often encountered situations and conditions of the scene that has been damaged by many people who want to see and even get into the scene, it is very difficult for investigators in the conduct crime scene processing.

In addressing these constraints, the efforts made are for Law Enforcement Officials, more thorough and more observant in using the provisions will be applied against the perpetrators in accordance with the rules of law that ? the applicable law and legal certainty to materialize and be more active in outreach to the community, especially women in order to avoid further cases of the same or other cases. In addition, the investigating authorities are given training and education to provide more knowledge about the case. As well as the police station for investigation and provide equipment and operating costs in accordance with the Butuhs of the investigation.

\section{Conclution}

The process of criminal investigation of infanticide by the biological mother is in police station, it took the Police Purworejo include investigators, attack (summons, arrest, detention, search, and seizure), inspection (witnesses, experts, and the suspect), and final completion and submission of the case file (manufacture resume, preparation of the dossier and submission of the case file)

The process of criminal investigation of infanticide by the biological mother can provide protection for children, in addition to whether or not made his case investigation conducted by the police of all elements also determine the chapter to be used against the offender. Investigators in the case of infanticide ensnared by the biological mother can use Article 80 paragraph (3), (4) by Act No. 35 Of 2014 on Amendment Act No. 23 of 2002 on the Protection of the Child, Article 338 of the Criminal Code, Article 181 of the Criminal Code, Article 341 of the Criminal Code and Article 342 of the Criminal Code or if possible can also put another article that satisfies the element. 
In the process of investigation of criminal offenses committed infanticide by the biological mother-Kendal there were limited both internally and externally, among others: 1 ) internally; investigators are still limited ability to lack of support equipment and operating costs. 2) externally; awareness and understanding of the general public against the law still does not give a positive contribution, there's also the reluctance of people to be willing to be a witness and at crime scenes often encountered situations and conditions of the scene that has been damaged by many people who want to see and even get into the scene,

In addressing these constraints, the efforts made are for Law Enforcement Officials, more thorough and more observant in using the provisions will be applied against the perpetrators in accordance with the rules of law that the applicable law and legal certainty to materialize and be more active in outreach to the community, especially women in order to avoid further cases of the same or other cases.

Based on these conclusions then given a suggestion that investigators hoped to build a better system in an effort to arrest the suspect, so the implementation of an investigation into the crime of infanticide committed by the biological mother normative and well done. In addition, the professionalism of the investigators more optimized. Hopefully, by the regulation concerning infanticide committed by the biological mother either the Criminal Code or other laws prevailing afford a basis for law enforcement officials to take action against any perpetrators of these crimes.

\section{Bibliography}

[1] Act No. 2 of 2002 on the Indonesian National Police.

[2] Act No. 23 of 2002 on Child Protection

[3] Act No. 39 of 1999 on Human Rights

[4] Civil Code

[5] Constitution of the Republic of Indonesia Of 1945

[6] Dadang Kahmad 2000 Metode Penelitian Agama CV Pustaka Setia Bandung.

[7] Evi Deliana HZ 2002"Perlindungan Hukum terhadap anak dari konten berbahahaya dalam media cetak elektronik," Jurnal Ilmu Hukum, Faculty of Law, University of Riau, August 2002 Edition III

[8] Herdian Ayu Andreana Beru Tarigan 2018 Upaya Penanggulangan Tindak Pidana Pembuangan Bayi di Kabupaten Boyolali Publication Paper, Faculty of Law, University of Muhammadiyah Surakarta.

[9] Kepolisian Negara Republik Indonesia Daerah Istimewa Yogyakarta Peran Scientificlnvestigation dalam Pengungkapan Kecelakaan/Kejahatan terhadap Manusia Paper stated in Medical Scientific Research Symposium on Law Enforcement in the anniversary of the Faculty of Medicine to-58 and RS Sardjito to-22.

[10] Nyoman Serikat Putera Jaya 1998 Penegakan Hukum Dalam Era Reformasi Delivered at an open senate meeting university of pekalongan, in the program of dies natalis XVI and under graduate convocation XII 5 September 1998

[11] O.Notohamidjojo 1975 Soal-soal Pokok Filsafat Hukum BPK Gunung Muria.

[12] Penal Code 
Jurnal Daulat Hukum Volume 1 Issue 3 September 2018 : 657 - 664

[13] Richard Quinney 1975 Criminology Analysis and Critique of crime in America Little Brown and Company Boston Toronto.

[14] Tatang M. Aminrin 2000 Menyusun Rencana Penelitian PT. Raja Grafindo Persada Jakarta. 